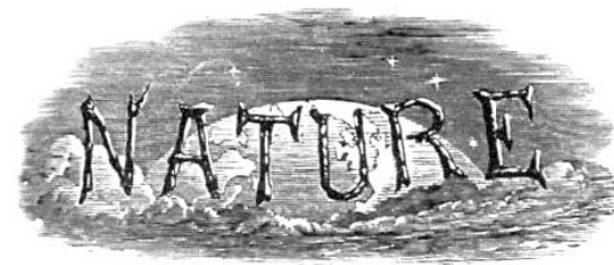

THURSDAY, APRIL 28, I92I.

Editorial and Publishing Offices:

MACMILLAN \& CO., LTD.,

ST. MARTIN'S STREET, LONDON, W.C.2.

Advertisements and business letters should be addressed to the Publishers.

Editorial communications to the Editor.

Telegraphic Address: PHUSIS, LONDON.

Telephone Number: GERRARD 8830.

\section{Agriculture and Fisheries in the Civil Service Estimates.}

$7 \mathrm{HE}$ vote to complete the sum of 3,2 I $1,60_{5} l$. for the salaries and expenses of the Ministry of Agriculture and Fisheries during the year 1921-22 was agreed to by the House of Commons on April ig. The amount of the vote shows a reduction of $2,156,107 l$. as compared with last year's Estimates; but three-quarters of this is due to the discontinuance of services arising out of the war. We view some of the decreases with mixed feelings; but before mentioning them specifically it is of interest to refer to one or two promising aspects of the Ministry's activities to which Sir A. Griffith-Boscawen directed attention in submitting the Estimates.

Considerable progress has been made with the Land Settlement Scheme for ex-Service men; 48,580 applications have been received, some of which have been rejected for various reasons, and it is estimated that 30,000 men will ultimately be settled. At the present time about I2, 000 men are already provided with holdings of $25^{\circ}, 000$ acres in the aggregate, and about 160,000 acres more are needed to complete the settlement. The scheme inevitably entails losses, foreseen from the beginning, and these may reach as much as 40 per cent. For the first seven years the losses will be made good to the county councils by the State, and after that the capital value will be written down to the then market value, and the holdings handed over on a self-supporting basis No. 2687 , VOL. IO7] to the county councils. In spite of the loss, it is considered that the settlement of 30,000 exService men on the land will prove a valuable asset to the State.

Foot-and-mouth disease still provides a great problem, as it has as yet proved to be impossible to determine how the infection is brought into the country. Although no trace of the disease can be found in Ireland, certain animals imported there have developed the disease within the incubating period, so that a quarantine of fourteen days at the ports is essential for some time to come. During 1920 there were ninety-four outbreaks in this country, involving the slaughter of more than 2000 cattle and 8000 sheep, with other animals, the net compensation paid being I I 5,oool. This policy of slaughter as compared with that of isolation and cure seems to be justified. In France, where the latter method is adopted, 855, I6I cattle were affected in 19r9-20, and the loss in the value of the animals was 5,000, oool. Muzzling against rabies has proved successful in preventing outbreaks for several months, except for a solitary case at Southampton, and loss through rats has been reduced by the campaign against them vigorously carried on since the passing of the Rats and Mice Destruction Act.

The project for manufacturing beet sugar at Kelham is so far advanced that it is hoped that the factory will be in running order this year. Meanwhile a further loan of $125,000 l$. on mort. gage is being made to the undertaking to meet the heavy initial costs of working.

The various councils and committees set up by the Agricultural Acts of 1919 and 1920 are in full working order, and are proving very useful. The policy adopted is that of decentralisation, as it is felt that there should be as little control as possible from Whitehall, but that the powers for insisting on good cultivation should be in the hands of the local committees, the members of which possess that local knowledge and interest which cannot possibly be had at headquarters. Both tenant farmers and labourers now enjoy a greater feeling of security on account of the new clauses dealing with compensation. Apparently, too, the guaranteed prices for wheat and oats are effectively checking the tendency to lay down land to grass, as this year the trade in grass seeds has been normal, with no exceptional buying.

All this is satisfactory enough; but the same can scarcely be said of the position of agricultural 
education and research in the Estimates, which show the following reductions compared with the Estimates for last year:-Agricultural and dairy education (grants in aid); 33,oool.; agricultural research (grants in aid), 6rool.; agricultural research, 6I, $190 l$. ; experiments and instruction in fruit preservation, $8745 l$. The only increase under the head of agricultural education and research is that of $3650 l$. for the National Institute of Agricultural Botany and Seed Testing Station. $B y$ the side of these great reductions we have an increase of $94,000 l$. in the estimate for salaries in the agricultural branch of the Ministry.

The Estimates for the Fisheries Department of the Ministry show similar decreases for research and similar increases on the administrative side. The differences may be summarised as follows :-

\begin{tabular}{|c|c|c|}
\hline & $1920-2 \mathrm{I}$. & $5921-22$. \\
\hline $\begin{array}{l}\text { Administration, salaries, } \\
\text { wages, allowances, legal } \\
\text { and incidental expenses. } \\
\text { All this properly called } \\
\text { Administrative Expendi- } \\
\text { ture. }\end{array}$ & $62,969 l$. & $85,434 l$ \\
\hline
\end{tabular}

The increased expenditure for $192 \mathbf{I}-22$ is 22,465 l.

Fishery research in general and fishery research grants in aid.

$59,700 i$.

$35,025 l$

Scientific Research.

The decreased expenditure for $192 \mathrm{I}-22$ is $24,675 \%$.

Shellfish research and development, development of inshore fisheries, economic destruction of inshore pests, elvers distribution scheme.

Development of Inshore Fisheries based on Scien. tific Research.

The decreased expenditure for $1921-22$ is $30,175 l$.

It will be seen that in each branch of the Ministry there has been a considerable increase in the cost of administration-that is, the cost of carrying out duties that are apart from scientific research and development. In the Fisheries Department, for example, the administrative staff employed in $1920-2 \mathrm{I}$ (secretaries, principals, clerks, writing assistants, typists, etc.) numbered sixty-two; but it is ninetyone in 1921-22. The inspectorial staff (that is, inspectors, technical assistants, fishery officers, surveyors, collectors of statistics, messengers, No. 2687 , vor. IO7] charwomen, etc.) was forty-eight in $1920-2 \mathrm{I}$; but it is sixty-two in $1921-22$. Against that we have a scientific staff of eighteen in 1920-2I, and of twenty-one in $192 \mathrm{I}-22$.

We search in vain for a justification of the increased expenditure on administration. The condition of the fishery industry is one of unprecedented depression. Big breaks in wages are contemplated or have been effected, and labour troubles are threatened. The withdrawal of the herring bounties is likely to lead to the laying up of half the East Coast fleets. Exporting has largely diminished. Inshore fishing is decadent. Either administration is impotent when confronted with such economic tendencies, or it thrives upon them. In the face of such industrial depression it is difficult to find a reason for the large increase in the cost of administering the fishery statutes. Frankly, we do not understand why the Ministry largely increases its administrative machinery while economising on development (which is surely the means of counteracting industrial depression) and on research (which provides the rationale for successful development). Obviously these Estimates ought to be explained and justified, if possible, for otherwise they suggest an incompetent administration, or a degree of misunderstood economy and control exerted by the Treasury against the better judgment of the Ministry. We might be inclined to take the latter view were it not for the increased cost of purely administrative services, which must have been suggested by the Ministry itself.

It is true that in the debate in the House of Commons Mr. Acland directed attention to the increased expenditure on administration and to the decreased provision for research, but no satisfactory explanation was forthcoming. So far as we are concerned, the opportunity for criticism is afforded only after Parliament has voted the money; and it will be the same next year, unless some body of scientific men obtains early copies of the Estimates and provides suitable representatives in Parliament with material evidence in support of their case for consideration. Criticism of the Estimates is, however, very difficult because of the form in which they are issued. It is impossible to resist the impression that the statement of the expenditure incurred and contemplated is made so as to convey the least possible informa. tion as to detail. This impression may be a mistaken one, but if it is the fault lies in the manner in which the Estimates are framed and published. 